\title{
Observations on the Astraeus spp. of Southwestern India
}

\author{
Pavithra M, Greeshma AA, Karun NC and Sridhar KR*
}

Department of Biosciences, Mangalore University, Mangalagangotri, Mangalore 574 199, India

Pavithra M, Greeshma AA, Karun NC, Sridhar KR 2015 - Observations on the Astraeus spp. of Southwestern India. Mycosphere 6(4), 421-432, Doi 10.5943/mycosphere/6/4/4

\begin{abstract}
Astraeus is a widespread genus of gasteromycete in tropical, sub-tropical and temperate regions. During mycological survey, two distinct species of Astraeus were recovered from the Southwestern India. Astraeus hygrometricus was frequent in forests of foothill region of the Western Ghats. In fire affected scrub jungles of the west coast, Astraeus odoratus was common and represents second report from the Indian Subcontinent. Astraeus spp. recovered were ectomycorrhizal in a variety of native and exotic tree species growing in sandy loam/gravel/pebblerich lateritic soils. Tender A. hygrometricus occurring in forests of foothill region of the Western Ghats serve as traditional nutritional delicacy and sold in local markets during rainy season.
\end{abstract}

Key words - Astraeus - Ectomycorrhizae - edibility - gasteromycete - macrofungi

\section{Introduction}

The gasteroid fungus Astraeus hygrometricus was first described in early 18th century as Geastrum by Persoon (1801). Subsequently, Morgan (1889) confirmed its identity as a distinct taxon Astraeus followed by more precise descriptions by many investigators (e.g. Lloyd 1902, Coker \& Couch 1928, Cunningham 1944). Astraeus belongs to the family Diplocystidiaceae (Boletales, Agaricomycetes, Basidiomycota) (Binder \& Bresinsky 2002, Kirk et al. 2008). This genus has worldwide distribution especially in the sandy soils of forests of Africa, Asia, Australia, Europe, Mexico, North America and South America (Lloyd 1902, Coker \& Couch 1928, Cunningham 1944, Dring 1964, Nouhra \& Toledo 1998, Phosri et al. 2004, Fangfuk et al. 2010).

Until now, up to 10 species have been described worldwide [(Astraeus asiaticus Phosri, M.P. Martin \& Walting, A. hygrometricus (Pers.) Morgan, A. koreanus (V.J. Staněk) Kreisel, A. morganii Phosri, Walting \& M.P. Martin, A. odoratus Phosri, M.P. Martin \& Whalley, A. pteridis (Shear) Zeller, A. sirindhorniae Walting, C. Phosri, N. Suwannasai, A.W. Wilson \& M.P. Martin, A. smithii Walting, M.P. Martin \& Phosri, A. telleriae M.P. Martin, Phosri \& Walting and A. thailandicus Petchart)] (Petcharat 2003, Phosri et al. 2013, Hembrom et al. 2014). Although Astraeus is superficially similar to Geastrum, it differs in certain characteristics especially lack of peristome and columella, consists of larger basidiospores than Geastrum and possesses highly branched long capillitial hyphae (Phosri et al. 2004). Astraeus is ectomycorrhizal and colonize a wide variety of forest tree species (e.g. Dipterocarpaceae, Fagaceae, and Pinaceae) unlike Geatrum with a few exceptions (e.g. G. saccatum and G. triplex are ectomycorrhizal) (Hibbett et al. 2000, Phosri et al. 2004, Fangfuk et al. 2010, Karun \& Sridhar 2014). According to Cannon \& Kirk (2007), convergent evolution might have occurred among Astraeus and Geastrum. 
Astraeus constitutes one of highly prized edible mushrooms in several parts of Asia (Mortimer et al. 2012). Tender basidiomata of Astraeus spp. are harvested in wild and marketed in India, Japan, Laos and Thailand (Ogawa 1992, Sanmee et al. 2003, Phosri et al. 2004, 2007, Dell et al. 2005, Butkrachang et al. 2007, Karun \& Sridhar 2014). Astraeus spp. are distributed widely in the Indian subcontinent (Himachal Pradesh, Jharkhand, Karnataka, Kerala, Orissa, Punjab, Uttarakhand, Uttar Pradesh and West Bengal) (Ahmad 1950, Phosri et al. 2004, 2013, Pradhan et al. 2010, 2013a, b, Mohanan 2011, Pyasi et al. 2011, Hembrom et al. 2014, Karun \& Sridhar 2014, Semwal et al. 2014). Due to meager information on Astraeus spp. especially in the Southern India (Bhagwat et al. 2005, Karun \& Sridhar 2014), traditional knowledge of its edibility in the foothill regions of the Western Ghats and their association with a variety of forest tree species stimulated the present study. Thus, morphology, distribution, association with tree species, traditional knowledge and edibility of two Astraeus spp. found in Southwestern India have been dealt in this paper.

\section{Materials \& Methods}

\section{Study sites and observations}

Based on the traditional knowledge on edible mushrooms, surveys were undertaken in and around Karkala forests (Udupi District, Karnataka) located in the foothill region of the Western Ghats $\left(13^{\circ} 12^{\prime} \mathrm{N}, 74^{\circ} 58^{\prime} \mathrm{E}\right)$. Specific forest locations consist of Astraeus include Chennibettu (67 m asl), Hebri (86 $\mathrm{m}$ asl) and Muniyalu (67 $\mathrm{m}$ asl). These are natural forest locations predominantly possess gravel, sandy and loamy lateritic soils. Astraeus was also seen in buffer zones of forestgrassland (or abandoned paddy fields) of Chennibettu. Another species of Astraeus was recovered from the fire affected scrub jungle in Konaje (90 m asl), near Mangalore University Campus (Dakshina Kannada District, Karnataka) $\left(12^{\circ} 49^{\prime} \mathrm{N}, 74^{\circ} 55^{\prime} \mathrm{E}\right)$. This location is adjacent to a road with rocky escarpment consisting of sandy, gravel and laterite soil.

General and specific morphological characteristics of Astraeus spp. obtained were compared with literature in the monographs (Jordan 2004, Phillips 2006, Mohanan 2011) and detailed descriptions (Phosri et al. 2004, 2013, Pyasi et al. 2011, Hembrom et al. 2014). Field photographs were taken using zoom camera (Sony DSC-HX100V and Nikon D40). Light microscopic details of Astraeus spp. were obtained using an Olympus Microscope (CX41RF) with camera attachment. For scanning electron microscopic (SEM) analysis, spores from mature fruit bodies were treated with ethanol series $(70 \%, 80 \%, 90 \%, 95 \%$ and twice in 100\%) and air-dried for overnight. Spores were mounted on stubs using sticky tabs and sputter coated with gold and observed in SEM (Joel, JSM 6380 LA, Japan). Snaps were taken by a digital camera (Nikon D40) mounted on a Stereomicroscope (Nikon, D40 USA).

For preservation of Astraeus spp. in herbarium of the Department of Biosciences, blotted specimens were transferred into water-ethanol-formaldehyde (14:5:1) in air-tight containers.

\section{Results}

Based on macro- and micro-morphological characteristics, Astraeus sp. found in Chennibettu has been assigned to A. hygrometricus, while another Astraeus sp. found in Konaje has been assigned to A. odoratus. Morphological details and diagnostic features are given along with their illustrations.

\section{Astraeus hygrometricus (Pers.) Morgan (Fig. 1A-H; Fig. 2A-J) (\# MUBSPMKRSMF-CBKA)}

Basidiomata: Creamish grey bulb surmounting a star-shaped pale purple grey base, which raises the spore sac above the surrounding substrate (Fig. 1G; Fig. 2C); scattered or in small groups (4-10), annual, particolous (Fig. 1A-C, F, H), infrequent to rare, taste excellent, odour mealy, edible (at immature stage) (Fig. 1D, E), ectomycorrhizal and measures 3 (3.5-4.6) $6.2 \mathrm{~cm}$ diam $\times$ $1.5(1.6-2.3) 2.5 \mathrm{~cm}$ tall $(\mathrm{n}=10)$ (Fig. 1G; Fig. 2C). Almost all the fruit bodies are partially buried in 
laterite soil (Fig. 1A, H). Majority of them are unopened or partially opened at apex with irregular crack of 4-7 petal-like lobes (Fig. 1G). With sufficient moisture, the lobes recurves, remain flat on the floor, further undergoes division about 7-13 lobes (Fig. 1G; Fig. 2C) and on drying lobes incurves towards centre (Fig. 2D). In most instances the lobes have tendency of incurving enclosing the spore sac. The spore sac degrades after the release of spores. The whole spore sac will be eliminated or its papery remnant remains at the centre of leathery incurved or flat lobes (Fig. 2 D-F). These left out lobes also have the capacity to recurve once imbibed with water and incurve on drying (Fig. 2D, E).

Immature basidiomata hypogeous, creamish, at first a small mycelial mass, with age globose to sub-globose to irregular, coarsely fibrous and arachnoid and measures $1.4(1.5-2.5) 3 \mathrm{~cm}$ diam $\times$ $1.2(1.4-2.3) 2.5 \mathrm{~cm}$ tall (Fig. $1 \mathrm{~A}-\mathrm{C}, \mathrm{F}-\mathrm{H})(\mathrm{n}=25)$. At maturity becomes epigeous. Immature washed basidiomata has typical baby potato-shape (Fig. 1D), besides many have 2 or 3 fused lobes (Fig. 1E) and each one at this stage is edible and ready for sale (1D, E). Immature fleshy basidiomes without or with a small black portion is edible than those have partial or intense purple brown colouration (Fig. 2A, B). Immature and mature basidiomes are directly attached to highly branched roots of host plants (Fig. 1H).
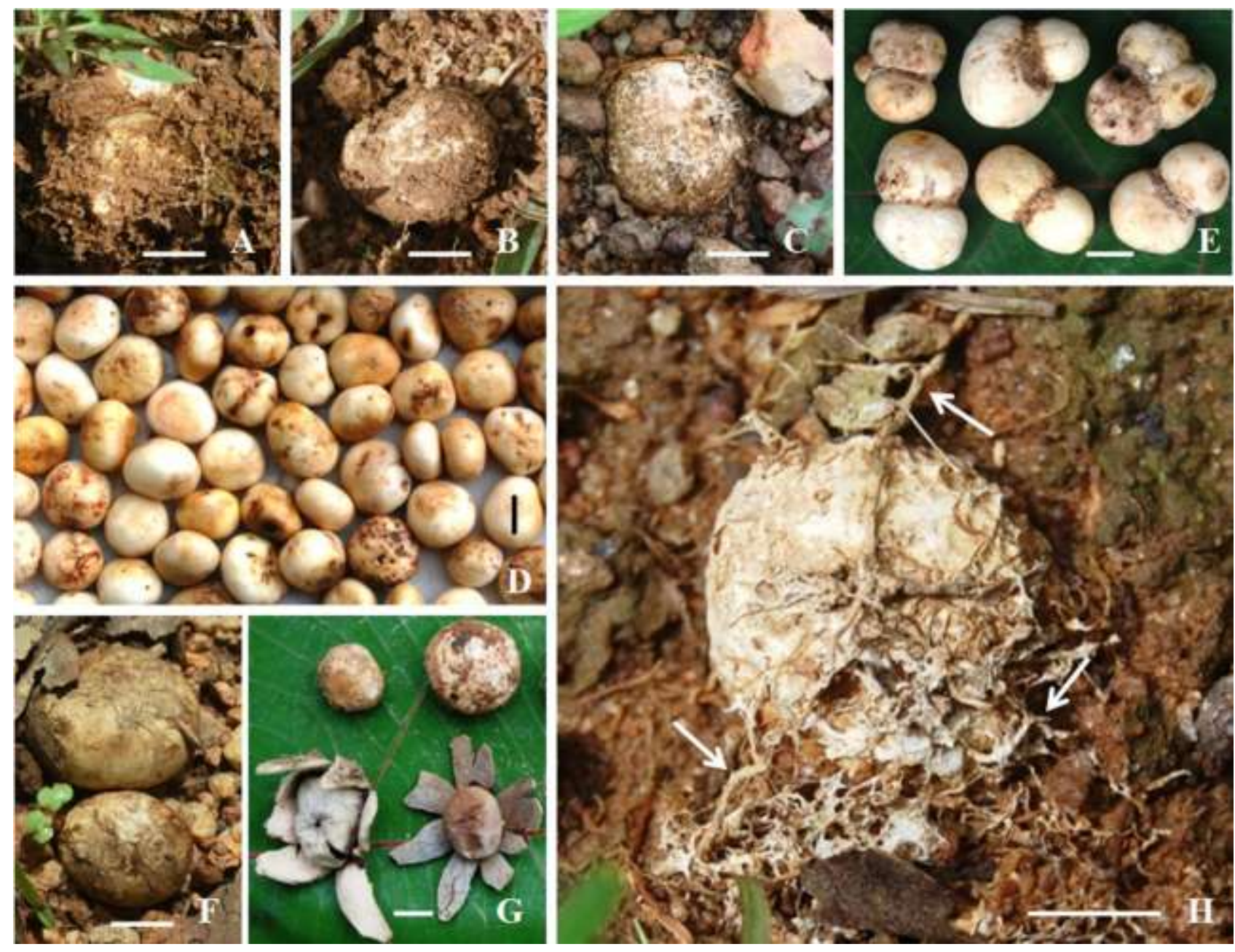

Fig. 1 - Astraeus hygrometricus: Partially hypogeus immature fruit bodies in sandy loam (deliberately exposed while sampling A, B) and gravel-/pebble-rich laterite soil (natural set up in field $\mathrm{C}, \mathrm{F}, \mathrm{H}$ ); immature fruit body attached to highly branched roots (arrows) of Hopea parviflora $(\mathrm{H})$; different stages of fruit bodies $(\mathrm{G})$; cleaned immature fruit bodies ready for sale/cook (D, E); cleaned 2-3 fused immature fruit bodies $(\mathrm{E})($ Scale: $1 \mathrm{~cm})$. 

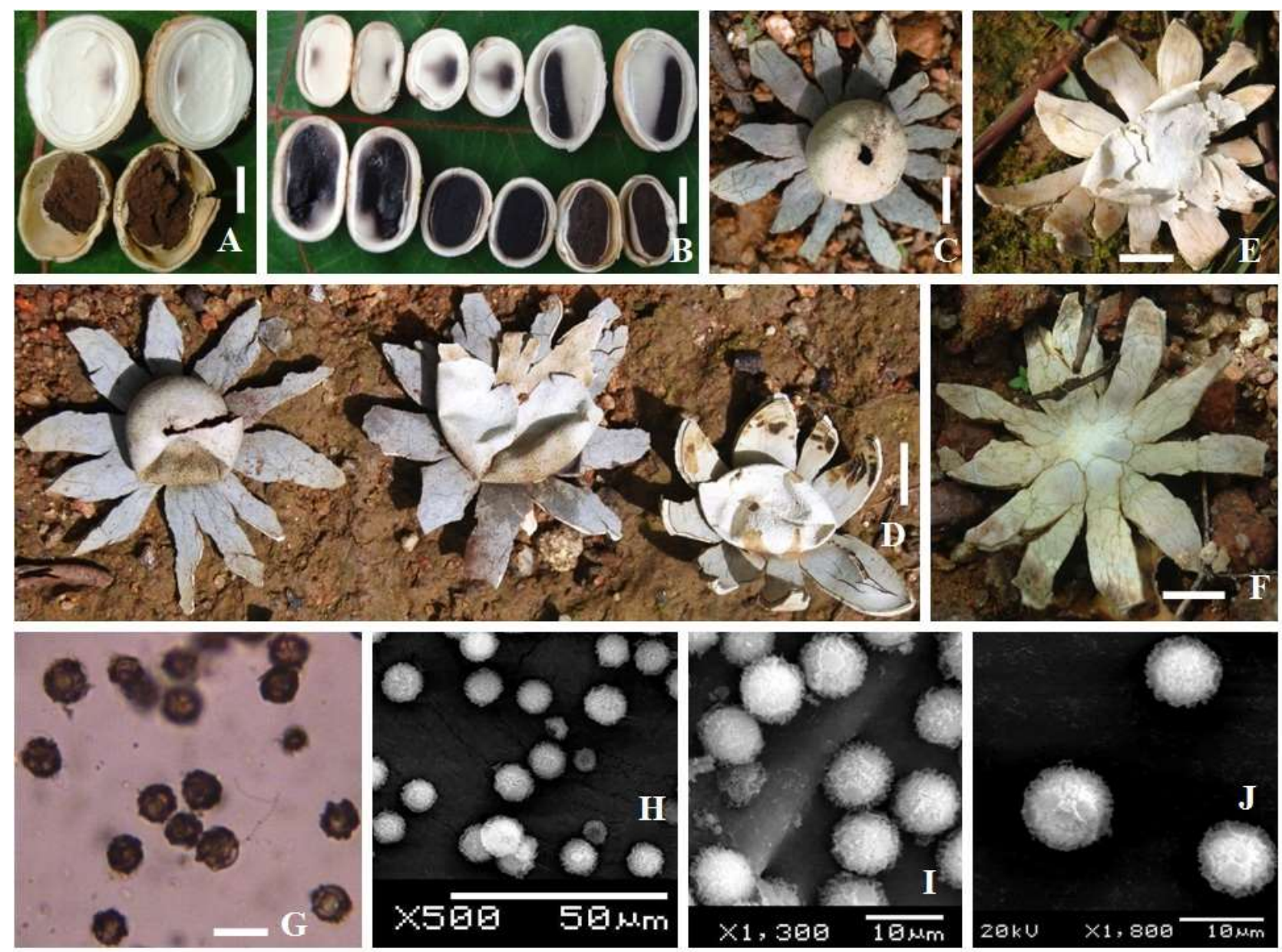

Fig. 2 - Astraeus hygrometricus in Chennibettu: Cross sections of immature and developing fruit bodies (A, B) (note several layers of outer wall in top 2 of A and shrunken interior in bottom 2 of A); fully matured (C) and partially degraded (D-F) fruit bodies on pebble-rich laterite soils (note: irregular opening in gleba in $\mathrm{C}$; partially bleached papery gleba in $\mathrm{D}$ and $\mathrm{E}$ ); ornamentation in basidiospores seen under light microscope $(\mathrm{G})$ and scanning electron microscope $(\mathrm{H}-\mathrm{J})$ (Scale: A-F, $1 \mathrm{~cm}$; G, I and J, $10 \mu \mathrm{m} ; \mathrm{H}, 50 \mu \mathrm{m})$.

Exoperidium: At maturity epigeous, exoperidium splits into 7-13 hygroscopic petal-like lobes; incurved when dry and recurved when moist \pm saccate (Fig. 1G; Fig. 2C). Pseudoparenchymatous layer was at first pinkish cream, becoming pale purple grey to greyish brown with age (Fig. 1G; Fig. 2C); at first fleshy, thin and smooth, becoming leathery with vertical and reticulate cracking with age. Mycelial layer was not encrusted with soil, radially fissured and there is a basal attachment point to the belowground mycelia.

Endoperidial body: Sub-spherical, $0.9(1-1.2) 2 \mathrm{~cm}$ diam $(\mathrm{n}=10)$ sessile and devoid of apophysis (Fig. 1G; Fig. 2C).

Endoperidium and gelba: Endoperidium at first ash grey and finely warty, becoming purple grey to creamish grey and smooth with age, thin, papery and opening by a slit or tear forming an irregular apical pore (Fig. 1G; Fig. 2C). Gleba at first white, fleshy, firm, with age becoming purple, finally become brownish and powdery (Fig. 1G; Fig. 2D, E).

Basidiospores: Purple brown, spherical, warty and measures 6.6 (7.9-12.5) $13.2 \times 5.3$ (6.6-12.5) $13.2 \mu \mathrm{m}$ (inclusive of ornamentation) (n=25) (Fig. 2G). Ornamentations on spores are clear, almost regular and consistent with less folds in SEM pictures (Fig. $2 \mathrm{H}-\mathrm{J}$ ). 
Astraeus odoratus Phosri, Walting, M.P. Martin \& Whalley (Fig. 3A-K; Fig. 4A-I) (\# MUBSPMKRSMF-FRKO)

Basidiomata: Brownish grey bulb surmounting a star-shaped, reflexed orange brown base, which raises the spore sac above the surrounding substrate; scattered or in small groups (4-8), annual, particolous (Fig, 3A, F; Fig 4A), infrequent to rare, taste and odour not distinctive, inedible, ectomycorrhizal and measures $4.4(4.5-7.5) 7.7 \mathrm{~cm}$ diam $\times 2.2(3.4-5.4) 5.7 \mathrm{~cm}$ tall $(\mathrm{n}=10)($ Fig. $3 \mathrm{~F}-\mathrm{J}$ ). Mature fruit bodies are usually above the laterite soil (Fig. 3F). During maturity, exoperidium irregularly cracks into 4-5 lobes and further breaks into 5-8 lobes (Fig. 3F-J). In moist condition, lobes curves out extensively and their tips take shelter on the ground (Fig. 3F). Under dry conditions, lobes neither incurve nor become flat (Fig. 3F-J). Usually the degraded gleba remains attached at the centre under wet or dry conditions (Fig. 3K).

Immature basidiomata hypogeous, creamish, at first a small mycelial mass, with age globose to sub-globose, coarsely fibrous, arachnoid and measures $1.2(1.7-3.5) 3.9 \mathrm{~cm}$ diam $\times 0.9(1-1.8)$ $2.9 \mathrm{~cm}$ tall (n=25) (Fig. 3A, B). Immature fruit body shows fleshy interior with layered sac (Fig. 3C, D), interior portion becomes brown and shrinks at later stage (Fig. 3E). At maturity becomes epigeous.
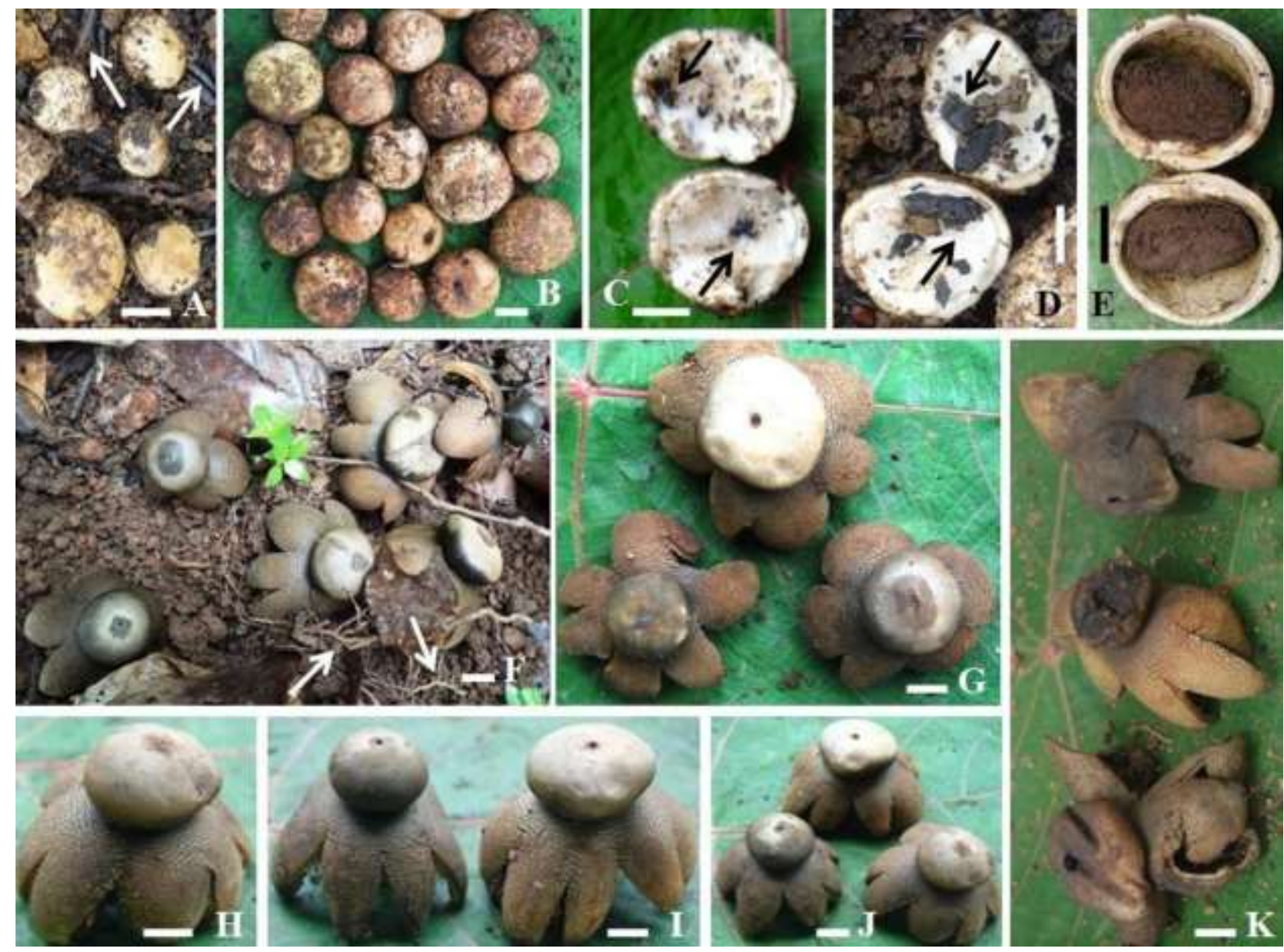

Fig. 3 - Astraeus odoratus in Konaje: Immature fruit bodies on loamy laterite floor (A) (arrows pointing charcoal pieces); immature fruit bodies of different size (B); sectioned immature (C, D) and maturing (E) fruit bodies (arrows pointing charcoal pieces in $\mathrm{C}$ and $\mathrm{D}$ ); a troop of mature fruit bodies on loamy laterite floor (arrows pointing roots of Hopea ponga) (F); top view $(\mathrm{G})$ and side views $(\mathrm{H}-\mathrm{J})$ of mature fruit bodies; stages of spent fruit bodies with attached gleba $(\mathrm{K})$ (Scale: 1 $\mathrm{cm})$. 

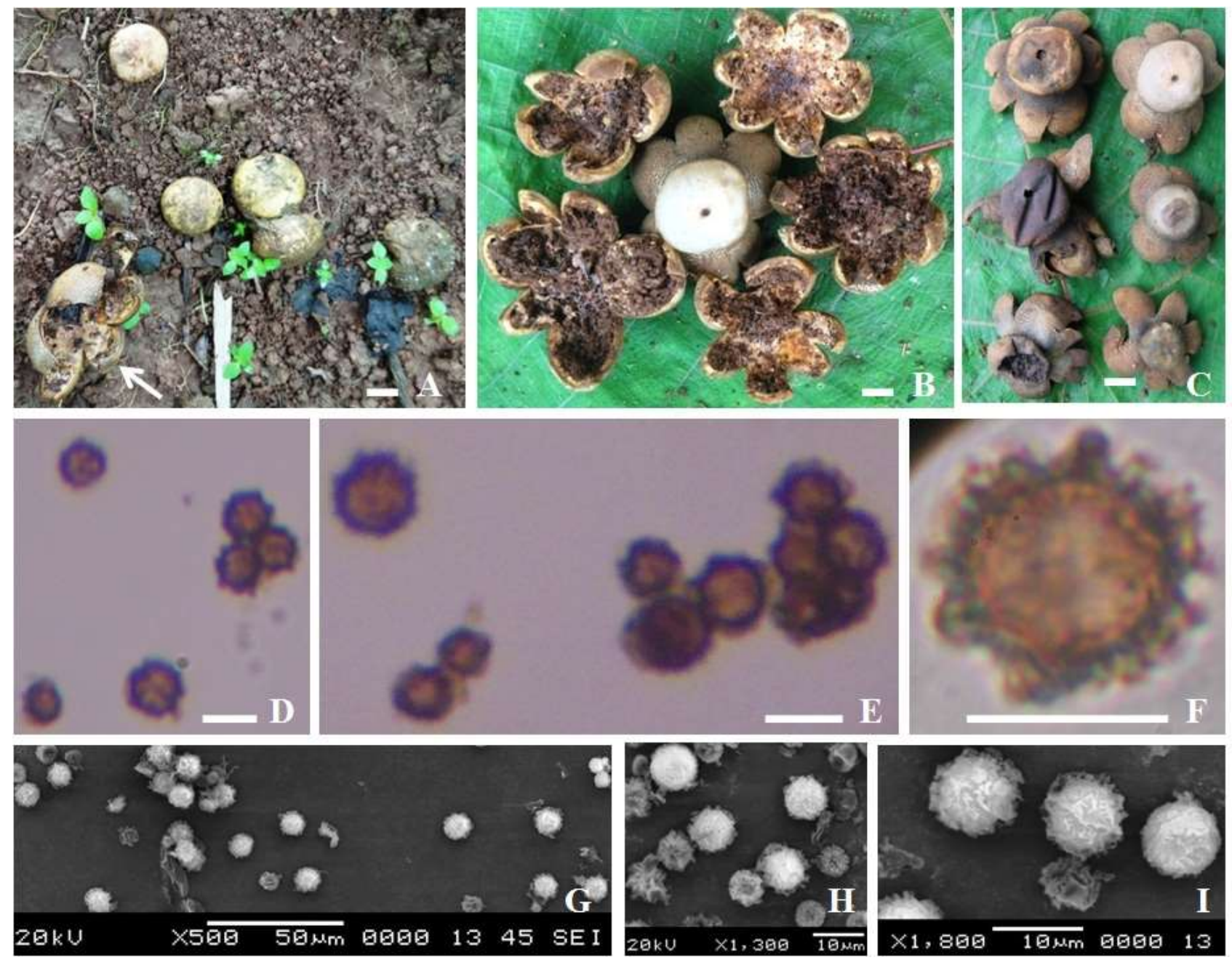

Fig. 4 - Astraeus odoratus in Konaje: Immature and mature fruit bodies on loamy laterite soil (A) (arrow pointing tilted mature fruit body showing hairy lobes); top view of upright and tilted mature fruit bodies (B) (note prominent hairy lobes in tilted fruit bodies); mature and spent fruit bodies of different stages $(\mathrm{C})$; ornamented basidiospores seen under low (D), high (E, F) power light microscope and scanning electron microscope (G-I) (Scale: A-C, $1 \mathrm{~cm}$; D-F, H, I: $10 \mu \mathrm{m}$; G, 50 $\mu \mathrm{m})$.

Exoperidium: At maturity epigeous, exoperidium splits into 5-8 non-hygroscopic petal-like lobes; curl upwards and inwards under the endoperidial body \pm involute (Fig. 3F-J). Pseudoparenchymatous layer at first pale orange becomes orange brown to brownish orange with age; at first fleshy, thick and smooth, becoming leathery, with fissured mosaic-like cracking with age (Fig. 3G-J). Mycelial layer was not encrusted with soil, radially fissured and there is a basal attachment point to the belowground mycelia. Posterior side of the mature basidiomata shows characteristic hairy/arachnoid feature seen on dry or partially dry conditions (Fig. 4A, B). As mature fruit body disconnects with roots, strong wind tilts it exhibiting hairy lobes of posterior region (Fig. 4A).

Endoperidial body: Sub-spherical, 1.85 (2.3-3.3) $3.4 \mathrm{~cm}$ diam $(\mathrm{n}=10)$, sessile and devoid of apophysis (Fig. 3F-J).

Endoperidium and gleba: Endoperidium at first grey brown and finely warty, becoming brownish grey and smooth with age, thin, papery and opening by a slit or tear forming an irregular apical pore (Fig. 3F-J). Gleba at first white, fleshy, firm, becomes purple with age, finally brownish and powdery (Fig. 3F-K; Fig. 4C). 
Basidiospores: Purple-brown, spherical, warty and measures $6.5(7.89-12.49) 13.15 \times 7.89$ (8.54-13.15) $13.8 \mu \mathrm{m}$ (inclusive of ornamentation) $(\mathrm{n}=25)$ (Fig. 4D-F). Ornamentations on spores are inconsistent, irregular and possess more folds on surface (Fig. 4F-I).

\section{Discussion}

In spite of high diversity of macrofungi in different biomes of varied geographic locations of the Indian Subcontinent, meager information is available on Astraeus. Until now, A. hygometricus was the only species reported from India and the second species $A$. odoratus was added recently by Hembrom et al. (2014). It has been reported from the Rajmahal Hills, sacred grove of Mandro Fossil Park and Dalabari Village of Jharkhand. In our study, A. odoratus found in the scrub jungle showed higher dimensions of basidiomata as well as basidiospores compared to the variety reported by Hembrom et al. (2014). On the contrary, dimensions of basidiomata, endoperidial body and basidiospores are smaller compared to the Thailand variety reported by Phosri et al. (2004). Rest of the properties including ornamentation in basidiospores are comparable with Indian as well as Thailand varieties (Phosri et al. 2004, Hembrom et al. 2014). A comparison of characteristics of $A$. hygrometricus and A. odoratus recorded in our study has been given in Table 1.

Table 1 Comparison of Astraeus species recovered from the Southwestern India (*based on traditional knowledge of local dwellers).

\begin{tabular}{|c|c|c|}
\hline & Astraeus hygrometricus (Fig. 1 \& 2) & Astraeus odoratus (Fig. 3 \& 4) \\
\hline Location & Forest Chennibettu, Karkala & Scrub jungle Konaje, Mangalore \\
\hline Substratum & Sandy and laterite soil & Sandy and laterite soil \\
\hline Immature fruit body $(\mathrm{cm})(\mathrm{n}=10)$ & $\begin{array}{l}1.4(1.5-2.5) 3 \text { diam } \times 1.2(1.4-2.3) 2.5 \\
\text { tall }\end{array}$ & $\begin{array}{l}1.2(1.7-3.5) 3.9 \text { diam } \times 0.9(1-1.8) \\
2.9 \text { tall }\end{array}$ \\
\hline Mature fruit body $(\mathrm{cm})(\mathrm{n}=25)$ & $\begin{array}{l}3(3.5-4.6) 6.2 \text { diam } \times 1.5(1.6-2.3) 2.5 \\
\text { tall }\end{array}$ & $\begin{array}{l}4.4(4.5-7.5) 7.7 \text { diam } \times 2.2(3.4-5.4) \\
5.7 \text { tall }\end{array}$ \\
\hline Number of rays/petals & $7-13$ & $5-8$ \\
\hline Folding of exoperidium & $\begin{array}{l}\text { Incurved when dry, recurved when } \\
\text { moist; } \pm \text { saccate. }\end{array}$ & $\begin{array}{l}\text { Curls upwards and inwards under the } \\
\text { endoperidial body; } \pm \text { involute }\end{array}$ \\
\hline $\begin{array}{l}\text { Texture of pseudo-paranchymatous } \\
\text { layer }\end{array}$ & $\begin{array}{l}\text { At first fleshy, thin and smooth, } \\
\text { becoming leathery with vertical, } \\
\text { reticulate cracking with age }\end{array}$ & $\begin{array}{l}\text { At first fleshy, thick and smooth, } \\
\text { becoming leathery with fissured } \\
\text { mosaic- like cracking with age }\end{array}$ \\
\hline $\begin{array}{l}\text { Colour of pseudo-paranchymatous } \\
\text { layer }\end{array}$ & Pale purple grey to greyish brown & Orange brown to brownish orange \\
\hline Colour of endoperidium & Purple grey to creamish grey & Grey brown to brownish grey \\
\hline Endoperidial body $(\mathrm{cm})(\mathrm{n}=10)$ & $0.9(1-1.2) 2$ & $1.9(2.3-3.3) 3.4$ \\
\hline Colour of gleba & Purple to brown & Purple to brown \\
\hline Basidiospore $(\mu \mathrm{m})(\mathrm{n}=25)$ & $\begin{array}{l}6.6(7.9-12.5) 13.2 \times 5.3(6.6-12.5) \\
13.2\end{array}$ & $\begin{array}{l}6.5(7.9-12.5) 13.2 \times 7.9(8.5-13.2) \\
13.8\end{array}$ \\
\hline Colour of basidiospores & Purple brown & Purple brown \\
\hline Ornamentation of spores & $\begin{array}{l}\text { Consistent, almost regular and possess } \\
\text { less folds on surface }\end{array}$ & $\begin{array}{l}\text { Inconsistent, irregular and possess } \\
\text { more folds on surface }\end{array}$ \\
\hline Ectomycorrhizal host tree species & $\begin{array}{l}\text { Anacardium occidentale, Artocarpus } \\
\text { hirsutus, Holigarna arnottiana, Hopea } \\
\text { parviflora, H. ponga, Phyllanthus } \\
\text { emblica and Syzygium cumini }\end{array}$ & Hopea ponga \\
\hline $\begin{array}{l}\text { Fresh weight of immature fruit } \\
\text { body }(n=25)\end{array}$ & $0.9-5.6 \mathrm{~g}$ & $3.2-10.4 \mathrm{~g}$ \\
\hline Edibility of immature fruit body & Edible* & Inedible* \\
\hline
\end{tabular}

\section{Habitats and hosts}

In India as well as far-east countries, Astraeus spp. dominates in the forest and scrub jungles in lateritic soils. In our study, A. hygrometricus was mainly confined to lateritic soils in natural 
forests and their adjacent open places (grass lands and abandoned paddy fields). The immature basidiomata were solitary or in cluster of $4-10$, fully or partially buried $(0.5-1 \mathrm{~cm})$ and sometimes visible along with pebbles of laterite soil as bone-white mycelial mass. Colonies of $A$. hygrometricus have been reported to grow in lateritic soils in the western (Karnataka and Kerala) and eastern (Orissa and West Bengal) parts of India (Pradhan et al. 2010, 2013a, b, Mohanan 2011, Karun \& Sridhar 2014, Manna \& Roy 2014). These were also occasionally found amidst Areca mixed plantation in lateritic soils of the west coast of Mangalore (Karun \& Sridhar 2014).

Astraeus spp. are ectomycorrhizal with plant families belonging to Betulaceae, Dipterocarpaceae, Ericaceae, Fagaceae and Pinaceae (Wilson et al. 2012). In our study, A. hygrometricus was ectomycorrhizal in tree species like Artocarpus hirsutus, Holigarna arnottiana, Hopea parviflora, H. ponga, Phyllanthus emblica and Syzygium cumini. Several ectomycorrhizal (Boletus sp., Hygrocybe sp., Russula sp. and Scleroderma citrinum) and non-ectomycorrhizal (Omphiolatus olearius and Psilocybe sp.) macrofungi were associated A. hygrometricus. Besides native tree species, A. hygrometricus was ectomycorrhizal in Acacia auriculiformis (invaded exotic tree species) and Anacardium occidentale (a major plantation crop of the Southwestern India). This is also an important ectomycorrizal fungus in the Shorea robusta in Sal forests in Orissa (Pyasi et al. 2011). They were also predominant in oak and pine forests (Surcek 1998) and ectomycorrhizal in Pinus densiflora in Japan (Fangfuk et al. 2010). Alnus, Castanea, Eucalyptus and Pseudotsuga were also hosts of A. hygrometricus (Trappe 1967, Molina 1979, Malajczuk et al. 1982, Nouhra \& De Toledo 1998). In vitro inoculation of spores of A. hygrometricus to Pinus densiflora resulted in formation of sheath, rhizomorphs and Hartig net in roots (Fangfuk et al. 2010).

Astraeus odoratus were collected mainly from the fire affected scrub jungle in Konaje village growing in lateritic soils in small troops of about 4-8. They were ectomycorrhizal in common tree species Hopea ponga. This mushroom was also associated with tree species Shorea robusta in Rajmahal Hills and Dalabari region of Jarkhand (Hembrom et al. 2014). There is a general notion that burning reduces the diversity of saprophytic macrofungi, but ectomycorrhizal fungi survive in subsoil along with roots. Sysouphanthong et al. (2010) opined that burning stimulates the growth of selected macrofungi especially A. hygrometricus. Besides A. odoratus is ectomycorrhizal in Hopea ponga in our study, it has also been reported as ectomycorrhizal with dipterocarps (Dipterocarpus tuberculatus var. tuberculatus and D, obtusifolius var. obtusifolius) in Northern Thailand (Kennedy et al. 2012). In vitro inoculation of spores and cultured mycelia of $A$. odoratus to Dipterocarpus alatus by Kaewgrajing et al. (2013) resulted in positive correlation with seedling growth. In Northern Thailand, yield of $A$. odoratus was significantly increased in burnt floors of dipterocarp-oak forests and serve as an important culinary delicacy as well as household income (Kennedy et al. 2012).

\section{Indigenous knowledge}

Astraeus spp. are known for several economic values especially edibility, medicinal properties and plant growth promotion as ectomycorrhizae. Generally, A. asiaticus, A. hygrometricus, A. odoratus and A. thailandicus are edible; A. koreanus and A. pteridis are inedible; edibility of rest of the species (A. morganii, A. sirindhorniae, A. smithii and A. telleriae) is yet to be established. Our study revealed that local people collect immature A. hygrometricus during early monsoon (June) to late monsoon (September). Usually, the highest yield will be during July and August. In mushroom dominant regions (forests, buffer zones and grass lands in laterite fields), local people identify troops of A. hygrometricus by scratching the surface of soil and looking for white matrix. Wherever white matrix seen on the surface or subsurface, it is a perfect indication that troops of immature fruit bodies prevail in its surroundings. Entire family of some tribes in and around Karkala region harvests tender A. hygrometricus throughout the day during rainy season for their livelihood. Harvesters find it easy to fetch more mushrooms in open and buffer zones than in typical forest locations. If bulk quantity of mushrooms is harvested, it can be preserved without processing under soil up to 3-4 days and desired quantity will be fetched for daily use. This indigenous method of preservation is also in practice in Eastern lateritic parts of India (Manna et al. 
2014). Harvested mushrooms will be cleaned in water to remove debris and hairy structures on the surface, wrapped in clean wet cloth and preserved as such or in refrigerators. Usually cleaned mushrooms will be cooked and consumed on same day or subsequent day. Collected tender $A$. hygrometricus reaches the local markets same day and sold in bulk or retail depending on the demand and reaches the nearby distribution centers (e.g. Moodbidri and Mangalore).

Before cooking, each immature basidium will be cut and ascertain its tenderness having white flesh inside. Those having fully white part or a small spec of black spot in the margin will be considered for eating and those having extended black regions will be discarded. In vernacular language (Kannada), this mushroom is called 'Kall-anabe' meaning 'stone mushroom'. This is one of the highly prized mushrooms costing Rupees 300-500 per kg, which is similar to the Termitomyces harvested in the Western Ghats and west coast region (Karun \& Sridhar 2013). A recent survey in the west coast revealed occurrence of A. hygrometricus in Areca plantation and likely consumed as traditional source of food (Karun \& Sridhar 2014).

The highest yield of $A$. hygrometricus was during July in the eastern lateritic region of India (Manna \& Roy 2014). In Thailand, A. hygrometricus has a long history of edibility and available in the rural markets (Phosri et al. 2013). This mushroom along with others (A. asiaticus and A. odoratus) will be harvested in wild from the Northern and North-Eastern part of Thailand for marketing (Dell et al. 2005, Butkrachang et al. 2007, Fangfuk et al. 2010). Another most edible species include A. thailandicus, which will also be collected and sold in the markets of Thailand (Petcharat 2003). There is a mixed opinion about the edibility of A. odoratus found in Konaje Village of Mangalore in our study.

Astraeus serve as herbal medicine in China and India (Mallick 2010). Ethnic tribes of Orissa in India, use Astraeus spp. traditionally for medicinal purposes (Panda \& Tayung 2014). Immunoenhancing activity of $A$. hygrometricus has been reported by Chakraborty et al. (2004) and Mallick (2010). The ethanolic extract of A. hygrometricus possesses significant free radical scavenging, lipid peroxidation inhibition and also possesses excellent anti-inflammatory activity comparable to the standard drug diclofenae (Biswas et al. 2010). Besides, ethanolic extract of $A$. hygrometricus also showed cardioprotective, chemoproventive, hepatoprotective and hypoglycemic potential (Biswas et al. 2011a, b, 2012, Biswas \& Acharya 2013). Anticandidal and leishmanicidal activities of $A$. hygrometricus have been reported by Lai et al. (2012).

\section{Outlook}

Exploration on Astraeus spp. has multiple benefits as they are edible (at least some species), medicinal (many of them) and ectomycorrhizal (almost all) in a variety of forest tree species. According to Hembrom et al. (2014), careful attention on exploration of Astraeus in the Indian Subcontinent yields more than widely accepted A. hygometricus. External appearance of Astraeus similar to Geastrum may be another reason for ambiguity and less attention. Phosri et al. (2013) suspected that Geastrum lilacinus described by Massee (1889) is an Astraeus species due to larger basidiospores. In addition to precise morphological observations, molecular approaches are certainly necessary to understand the Astraeus complex.

\section{Acknowledgements}

Authors are grateful to Mangalore University for permission to carry out this study in the Department of Biosciences. One of us (GAA) greatly acknowledges the award of INSPIRE Fellowship, Department of Science and Technology, New Delhi, Government of India (Fellowship \# IF140953). KRS is grateful to the University Grants Commission, New Delhi, India for the award of UGC-BSR Faculty Fellowship.

\section{References}

Ahmad S. 1950 - Studies in gasteromycetes. Sydowia 4, 124-129. 
Bhagwat S, Kushalappa C, Williams P, Brown N. 2005 - The role of informal protected areas in maintaining biodiversity in the Western Ghats of India. Ecology and Society 10, http://www.ecologyandsociety.org/vol10/iss1/art8/

Binder M, Bresinsky A. 2002 - Derivation of a polymorphic lineage of gasteromycetes from boletoid ancestors. Mycologia 94, 85-98.

Biswas G, Acharya K. 2013 - Hypoglycemic activity of ethanolic extract of Astraeus hygrometricus (Pers.) Morg. in alloxan-induced mice. International Journal of Pharmacy and Pharmaceutical Sciences 5, 391-394.

Biswas G, Chatterjee S, Acharya K. 2012 - Chemopreventive activity of the ethanolic extract of Astraeus hygrometricus (Pers.) Morg. on Ehrlich's ascites carcinoma cells. Digest Journal of Nanomaterials and Biostructures 7, 185-191.

Biswas G, Sarkar S, Acharya K. 2010 - Free radical scavenging and anti-inflammatory activities of the extracts of Astraeus hygrometricus (Pers.) Morg. Latin American Journal of Pharmacy 29, 549-553.

Biswas G, Rana S, Acharya K. 2011a - Cardioprotective activity of ethanolic extract of Astraeus hygrometricus (Pers.) Morg. Pharmacologyonline 2, 808-817.

Biswas G, Sarkar S, Acharya K. 2011b - Hepatoprotective activity of the ethanolic extract of Astraeus hygrometricus (Pers.) Morg. Digest Journal of Nanomaterials and Biostructures 6, 637-641.

Butkrachang S, Boonchieng E, Sardsud U, Sukchotiratana M, Plikomol A, Chairote G, Narongchai P. 2007 - Wild mushroom database of Chiang Mai community forest. Asian Journal of Biology 3, 65-70.

Cannon PF, Kirk PM. 2007 - Fungal Families of the World. CAB International, UK.

Chakraborty I, Mondal S, Pramanik M, Rout D, Islam SS. 2004 - Structural investigation of a water-soluble glucan from an edible mushroom, Astraeus hygrometricus. Carbohydrate Research 339, 2249-2254.

Coker WC, Couch JN. 1928 - The Gasteromycetes of the Eastern United States and Canada. University of North Carolina Press, Chapel Hill.

Cunningham GH. 1944 - The Gasteromycetes of Australia and New Zealand. Published by the author.

Dell B, Sanmee R, Lumyong P, Lumyong S. 2005 - Ectomycorrhizal fungi in dry and wet dipterocarp forests in northern Thailand - Diversity and use as food. Proceedings of the $8^{\text {th }}$ Round Table Conference on Dipterocarps, Ho Chi Minh, Vietnam.

Dring DM. 1964 - Gasteromycetes of West Tropical Africa. Mycological Papers 98, 1-60.

Fangfuk W, Petchang R, To-anun C, Fukuda M, Yamada A. 2010 - Identification of Japanese Astraeus, based on morphological and phylogenetic analyses. Mycoscience 51, 291-299.

Hembrom ME, Parihar A, Martín MP, Walting R, Das K. 2014 - First report of Astraeus odoratus from India. Kavaka 42, 16-19.

Hibbett DS, Gilbert L-B, Donoghue MJ. 2000 - Evolutionary instability of ectomycorrhizal symbiosis in basidiomycetes. Nature 407, 506-508.

Jordan M. 2004. The Encyclopedia of Fungi of Britain and Europe. Francis Lincoln Publishers Ltd., London.

Kaewgrajing T, Sangwanit U, Iwase K, Kodama M, Yamato M. 2013 - Effects of ectomycorrhizal fungus Astraeus odoratus on Dipterocarpus alatus seedlings. Journal of Tropical Forest Science 25, 200-205.

Karun NC, Sridhar KR. 2013 - Occurrence and distribution of Termitomyces (Basidiomycota, Agaricales) in the Western Ghats and on the west coast of India. Czech Mycology 65, 233254.

Karun NC, Sridhar KR. 2014 - A Preliminary Study on Macrofungal Diversity in an Arboretum and Three Plantations of the Southwest Coast of India. Current Research in Environmental \& Applied Mycology 4, 173-18. 
Kennedy KH, Maxwell JF, Lumyong S. 2012 - Fire and the production of Astraeus odoratus (Basidiomycetes) sporocarps in deciduous dipterocarp-oak forests of northern Thailand. Maejo International Journal of Science and Technology 6, 483-504.

Kirk PM, Cannon PF, Minter DW, Stalpers JA. 2008 - Dictionary of the fungi, 10th Edition. CAB International, Wallingford, UK.

Lai TK, Biswas G, Chatterjee S, Dutta A, Pal C, Banerji J, Bhuvanesh N, Reibenspies H, Acharya K. 2012 - Leishmanicidal and anticandidal activity of constituents of Indian edible mushroom Asraeus hygrometricus. Chemistry \& Biodiversity 9, 1517-1524.

Lloyd CG. 1902 - The Geastreae. Mycological Writings 1, 1-44.

Malajczuk N, Molina R, Trappe JM. 1982 - Ectomycorrhizal formation in Eucalyptus. I. Pure culture synthesis, host specificity and mycorrhizal compatibility with Pinus radiata. New Phytologist 91, 467-482.

Mallick SK, Swatilekha M, Bhutia SK, Maiti TK. 2010 - Immunostimulatory properties of a polysaccharide isolated from Astraeus hygrometricus. Journal of Medicinal Food 13, 665672.

Manna S, Roy A. 2014 - Economic contribution of wild edible mushrooms to a forest fringe ethnic community in some eastern lateritic parts of India. Journal of Forest Research 19, 52-61.

Manna S, Ray D, Roy A. 2014 - Tribal relation to spatio-temporal variation of wild mushrooms in eastern lateritic part of India. Ethnobotany Research \& Applications 12, 15-24.

Massee G. 1889 - New or imperfectly known gasteromycetes. Grevillea 19, 94-98.

Mohanan C. 2011 - Macrofungi of Kerala. Kerala Forest Research Institute, Hand Book \# 27, Kerala, India.

Molina R. 1979 - Pure culture synthesis and host specificity of red alder mycorrhizae. Canadian Journal of Botany 57, 1223-1228.

Morgan AP. 1889 - North American Fungi: The Gastromycetes. Journal Cincinnati Society Natural History 12, 8-22.

Mortimer PE, Karunarathna SC, Li Q, Gui H, Yang X, Yang X, He J, Ye L, Guo J, Li H, Sysouphanthong P, Zhou D, Xu J, Hyde KD. 2012 - Prized edible Asian mushrooms: Ecology, conservation and sustainability. Fungal Diversity 56, 31-47.

Nouhra ER, De Toledo DL. 1998 - The first record of Astraeus hygrometricus from Argentina. Mycologist 12, 112-113.

Ogawa M. 1992 - How to cultivate wild mushrooms. Zenrinkyou, Tokyo.

Panda MK, Tayung K. 2014 - Ethnobotanical knowledge of wild edible mushrooms among ethnic tribes of Northern Odisha, India and antimicrobial activities of two mushroom species. Abstract \# MD 40, $55^{\text {th }}$ Annual Conference of Association of Microbiologists of India.

Persoon CH. 1801 - Synopsis methodica fungorum. H. Dieterich, Göttingen.

Petcharat V. 2003 - Edible Astraeus (Basidiomycota) from Thailand. Nordic Journal of Botany 23, 499-503.

Phillips R. 2006 - Mushrooms. Pan Macmillan, London.

Phosri C, Watling R, Martín MP, Whalley AJS. 2004 - The genus Astraeus in Thailand. Mycotaxon 89, 453-463.

Phosri C, Martín MP, Sihanonth P, Whalley AJS, Watling R. 2007 - Molecular study of the genus Astraeus. Mycological Research 111, 275-286.

Phosri C, Martin PM, Walting R. 2013 - Astraeus: Hidden Dimensions. IMA Fungus, 4, 347-356.

Pradhan P, Banerjee S, Roy A, Acharya K. 2010 - Role of wild edible mushrooms in the Santal livelihood in lateritic region of West Bengal. Journal of Botanical Society of Bengal 64, 61-65.

Pradhan P, Dutta AK, Roy A, Basu SK, Acharya K. 2013a - Inventory and spatial ecology of macrofungi in the Shorea robusta forest ecosystem of lateritic region of West Bengal. Biodiversity 13, 88-99.

Pradhan P, Dutta AK, Roy A, Basu SK, Acharya K. 2013b - Macrofungal diversity and habitat specificity: A case study. Biodiversity 14, 147-161. 
Pyasi A, Soni KK, Verma RK. 2011 - Dominant Occurrence of Ectomycorrhizal Colonizer Astraeus hygrometricus of Sal (Shorea robusta) in Forest of Jharsuguda, Orissa. Journal of Mycology and Plant Pathology 41, 222-225.

Sanmee R, Dell B, Lumyong P, Izumorid K, Lumyong S. 2003 - Nutritive value of popular wild edible mushrooms from Northern Thailand. Food Chemistry 82, 527-532.

Semwal KC, Stephenson SL, Bhatt VK, Bhatt RP. 2014 - Edible mushrooms of the Northwestern Himalaya, India: A study of indigenous knowledge, distribution and diversity. Mycosphere 5, 440-461.

Surcek M. 1998 - The Illustrated Book of Mushrooms and Fungi. Octopus Books, Czechoslovakia.

Sysouphanthong P, Thongkantha S, Zhao R, Soytong K, Hyde KD. 2010 - Mushroom diversity in sustainable shade tea forest and the effect of fire damage. Biodiversity and Conservation 19, 1401-1415.

Trappe JM. 1967 - Pure culture synthesis of Douglas-fir mycorrhizae with species of Hebeloma, Suillus, Rhizopogon, and Astraeus. Forest Science 13, 121-130.

Wilson AW, Binder M, Hibbett DS. 2012 - Diversity and evolution of ectomycorrhizal host associations in the Sclerodermatineae (Boletales, Basidiomycota). New Phytologist 194, 1079-1095. 